\title{
富士山における戦後の美化清掃活動の変遷
}

\section{Transition of the Beautification and Cleaning Activities in Mt. Fuji Area after World War II}

佐山 浩* 西田 正憲**

Hiroshi SAYAMA Masanori NISHIDA

\begin{abstract}
摘要 : 富士山の戦後の美化清掃活動について, その動きを全国的視野から位置づけるとともに実態等 の経緯をたどり，社会的背景を考察することによって，富士山の美化清掃活動の変遷の特徴を明らか にする。その結果, 富士山の美化清掼活動は, (1)東京オリンピックを背景に国土美化の一環として始 まり，(2)交通の発達及び利用者の増大を背景にゴミ問題が深刻化し，景観問題から生態系問題へ変化 しつつ, 広範な市民参加を促した。その後(3)世界遺産登録運動等を契機として, 山梨・静岡両県等の 連携のもと，環境保全意識の高まりとともに、広範な環境保全活動と一体化していったと指摘できる。
\end{abstract}

\section{1.はじめに}

明治後期以降，我が国の象徵として崇められてきている富士山 は1)，日本に於いて最も高く，最も美しい山容を誇る。本富士山 地域は 1936 年に国立公園に指定され，富士五湖等周辺域を含め て数多くの人が訪れている。特に富士山には夏期の短期間に登山 者等利用者が集中すること等により，ゴミ問題が遠速く生じた。

本論は, (1)富士山の戦後の美化清掃活動の動きを全国的視野か ら位置づけ，(2)富士山の戦後から現在にかけての美化清掃活動の 経緯をたよ゙り，(3)社会的背景を考察することによって，(4)富士山 の美化清掃活動の変遷の特徽を明らかにすることを目的とする。 方法は, 既存の行政資料, 文献, 観光統計, 新聞記事等及び現地 調查から，官民の美化清掃活動内容，利用者，ゴミ収集量，収集 者等の変化及び富士山をめぐる社会的背景を分析することにより, 特徴を明らかにするあのである。

本論で対象としている富土山地域は，かかる山容及び山麓のう ち, 特に五合目以上の山容を指す。国立公園の美化清掃活動は, (1)行政が自ら実施するもの，(2)行政の援助を得て清掃団体が実施 するもの，(3)行政，民間の提唱によりボランティア等市民参加に よって実施するもの，(4)79年に設立された(財)自然公園美化管 理財団等の公的機関が駐車料を還元する形で実施するものが一般 的であり，本論においてもこれらを対象としている。美化清掃活 動については, 鹿野 2 が国立公園内の清掃補助制度及び費用負担 について，佐山 ${ }^{3)}$ が利用者に視点を当てて国立公園を含む自然公 園内の活動の経緯について論じている。富士山に関しては, 国土 を美しくする運動中央推進委員会 ${ }^{4}$ が 62 年の活動について, 中 沢 $^{5)}$ 及び池谷 ${ }^{6)}$ が 62,63 年の活動について論じている。また, 沖 ${ }^{72}$ が 65 年前後の登山者の実態及び活動等について, 小森 ${ }^{8}$ が 69 年度の活動の実態について, 日下部, 遠藤及び石川 ${ }^{97}$ が 79 年 の富土山クリーン作戦を論じている。本論は一部これらを踏まえ つつ, 富士山における美化清掃活動を通観し, その変遷の特徴を 論じるものである。

\section{2. 全国の国立公園と富士山の美化清掃活動}

我が国では, 国立公園利用者の急増する昭和 30 年 (1955 年)

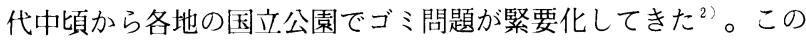
ため， 62 年に富士山では官民が協力して「富士山をきれいにす る会」が, 翌 63 年には上高地において「上高地を美しくする会 $\rfloor^{10)}$ が
発足した。また，国においても国立公園集団施設地区とその周辺 地域の美化をモデル的に推進するため, 63 年度に初めて 161 万 円の美化対策費を予算化し，美化清掃活動を進め"1)，富士山にお いても 67 年度から活動を開始した。富士山の美化清掃活動はこ の時期先導的事例を示していた。昭和 40 年（65 年）代以降にな ると全国的にゴミ問題は深刻化の兆しを見せた。国はこうした状 況を踏まえ，70 年に自然公園法を改正，自然公園法第 16 条の 2 を追加し，国として国立公園内の清掃の一端を担うようになった。 また，71 年度から国立公園内に設置する焼却炉等の清掃設備に 対する清掃設備整備費補助制度を, 74 年度には地域の清掃団体 が行う清掃活動に対する清接活動費補助制度を発足させた。一方, 71 年に志賀高原, 以後, 尾瀬, 白山, 大雪山 ${ }^{3}$ 等, そして 78 年 には富士山でゴミ持ち帰り運動が始まった。ゴミ持ち帰り運動は 利用者個々人の意識と行動に拠るところが大きいが， 79 年には 富士山クリーン作戦が寒施され，2 万 4 个人を超える人が参加し た ${ }^{9 !}$ 。これは，市民参加による一斉清掃の先駆けとなり，全国的 な展開を招来し，81 年には国立公園制度 50 周年を記念して 8 月 の第 1 日曜日が「国立公園クリーンデー」と定められ， 83 年に は「自然公園クリーンデー」と変更, 毎年, この日を中心に全国一 斉の美化清掃活動が国立公園等の自然公園で展開されることとなっ た。全国的視野から概観すると, 富士山地域の美化清掃活動は, 我 が国の国立公園において常に先進的な位置にあったと指摘できる。

\section{3. 富士山の戦後から現代にかけての美化清掃活動の経緯}

富士山の戦後の美化清掃活動の経緯について, 前述の全国的な 動き屯念頭に, 美化清掃活動の開始, 本格化, その後の発展に整 理して, 実態をたどる。これらの活動に関する主な出来事を表一 1 に整理した。

\section{（1）ゴミ問題の緊要化と美化清掃活動の開始}

富士山における戦後の大規模な美化清掃活動は, 1962 年, 新 生活運動協会の「国土を美しくする運動」(略称「国土美運動」) を起点として始まる。国土美運動は「生活者である国民みづから が，自分たちの生活環境を美しくするために，まずお互いが民主 社会のよき市民であるための市民性を高め, 公共精神をやしなう ことを精神的な柱とし」〉)て 3 年間の活動として東京オリンピッ クの開催される 64 年をひとつの目標に進められたものであるが, 富士山においては, 新生活運動協会を中心として, 山梨・静岡両

\footnotetext{
“環境省南関東地区自然保護事務所 $\cdots$ 奈良県立商科大学商学部
} 
県の諸組織から構成された実行委員会により推進された。

この過程で野口二郎山梨県観光連盟会長（当時）が提唱した美 化運動 ${ }^{12}$ は，地元を中心とした美化清掃団体である「富士山をき れいにする会」に結びついた。この時期は，ゴミ問題が緊要化し ていく時期であり，国も 67 年度から富土山でアルバイト雇用に よる清掃活動を開始した。

\section{（2）ゴミ問題の深刻化と美化清掃活動の本格化}

前述の上おり 67 年度から国により始められた清掃活動む山梨・ 静岡両県や富士山をきれいにする会とも協力しながら活動を展開 した ${ }^{8)}$ 。しかし，ゴミの収集量は減少するどころか増加傾向を示 し，70 年代にはゴミ問題は深刻化し，富士山をきれいにする会 に参加する団体も 74 年頃から急増していく（図一 1)。ゴミ収集 量も 79 年のピークに向かうが，美化清掃活動も様々に展開し， 本格化していく。77 年 7 月 16 日には陸上自衛隊富士教導団の隊 員 2 千人がゴミ一掃作戦を展開し，約 6 トンのゴミを回収した ${ }^{13 \%} 。$ また 78 年度には, 環境庁において富士山頂特別清掃費約 200 万 円が計上されたことにより，ゴミの収集処理とゴミ持ち帰り運動 の推進等の美化清掃活動が実施された。特に 8 月 5 日〜 6 日の環 境庁職員のボランティアによる清掃登山の呼びかけに，環境庁長 官をはじめ約 80 名が参加した。これらを契機として，78 年 12 月に環境预自然保護局長, 山梨・静岡両県知事の 3 者加構成さ れる富土山自然環境保全対策会議が設立, 79 年 6 月 23 日には環 境庁, 山梨・静岡両県が中心となり, 地元の各団体及び自衛隊等 の協力を得て, 富土山クリーン作戦が実施され, 山梨・静岡両県 全体で参加者 $24 ， 295$ 人，ゴミ収集量約 197 トンを記録した ${ }^{9)}$ 。 翌年には，国庫補助を受けて美化清掃活動を行う时体として，山 梨県には「富士山及び周辺美化推進協議会」が，静岡県には「富 士山をいつまでも美しくする会」が設立, 80 年度から美化清掃 事業が継続して実施されているとともに, 静岡県側においても地 元住民を主体とした一斉清掃が行われ，美化清掃活動が定着した。

\section{（3）広範な環境保全活動の展開}

以後, 美化清掃活動が定着し, ゴミ持ち帰り運動も各行政機関, 清掃闷体及び山小屋等の呼びかけにより徐々に浸透していく中, ゴミ収集量む横這いか滅少傾向 ${ }^{(4)}$ を見せ, 美化清掃活動は広範な

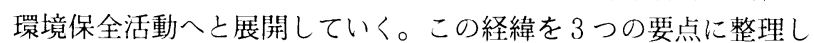
て述べる。

\section{（i）環境保全に対する新たな注目}

1988 年に大沢崩れを防止するため民間団体の土だんごによる 緑化が行われたが, 保護団体及び研究者等による反対運動が起こ り, 富士山の環境保全への関心を高めた。また，行政においては, 89 年の富士五湖の静䍀な環境を守るための条例の施行, 91 年の 国立公園地域における車馬乗り入れ規制区域の指定等, 環境保全 対策が講じられる。こうした状況の中，91 年 8 月に山梨県が立. 体駐車場建設計画を含めた「富士山五合目等の利用環境の適正化 に関する計画」を発表するが，自然保護団体等の反発を招き ${ }^{15)}$, 結果的に計画は白紙撤回された。これを契機に地元を中心に自然 保護運動が盛り上がり, 丁度, 日本が 92 年に世界遺産条約を批 准した時期之重なり，富土山世界遺産登録運動へと発展していっ た。この運動は, 最終的に約 246 万人の署名を集め, 94 年 12 月 の「富士山の世界遗産リストへの登録を目指して富士山の保全対 策を検討するなど積極的な取り組み」を趣旨とする「富士山の世 界遺産リストの登録に関する請願」の衆参雨議院での採択へ之結 びついた。これを受けて, 関係行政機関からなる富士山環境保全 対策協議会が発足, 95 年 7 月に当面緊急を要する環境保全対策 を中間報告としてま之め, 98 年 3 月には富士山の環境保全を図 るための利用者のルールである富士山カントリーコードを盛り込 んだ富士山環境保全対策要綱を策定した。ここに富士山において は, 美化清掃問題のみならず様々な環境保全問題が捉えられるよ
表ー1 富士山地域を中心とした美化清掃等に係る主な動き
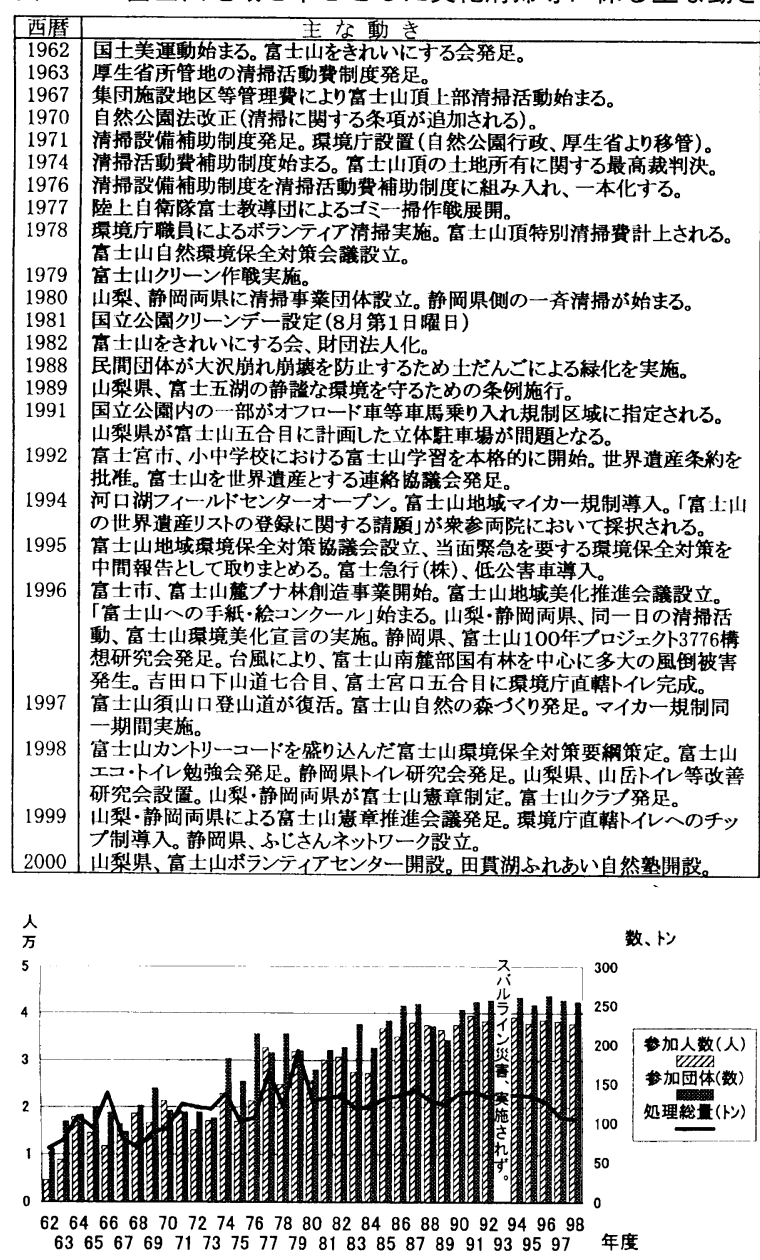

図ー1 （財)富士山をきれいにする会活動実績

うになった。

（ii）し尿処理問題の浮上とチップ制トイレの導入

この富士山環境保全対策協議会の検討過程で，ゴミ問題がし尿 処理問題之一体となって新たな環境問題として再認識されること となる。高山で自然条件が厳しく，しかも夏の 2 ヶ月間に多数の 登山利用者が集中する富士山では, 分解しないゴミやティッシュ の散乱は単に景観のみならず生態系に悪影響を与える等, ゴミ之 し尿処理対策が環境保全の大きな課題として浮上してくる。この ような環境保全上の観点から 96 年 5 月に発足した富士山地域美 化推進会議が中心となって，山梨・静岡両県での一斉清掃の同一 日実施の他，98，99 年には分解しないティッシュ等に起因する 白い川問題 ${ }^{16)}$ を解消するため水解性ティッシュの作成・配布を行つ た。そして 98 年には山梨・静岡雨県双方にトイレ研究会が設置 された。

また，特にし尿処理対策の一環として，96 年に環境庁が富士 吉田口下山道七合目之富士宮口五合目に設置した公衆トイレに拄 いて, 利用者から自発的なチップを取る協力金制度が 99 年から 導入された。本トイレのチップ制導入を通じて，管理が困難かつ 維持経費のかかる山岳トイレへの関心之環境保全問題への理解を より一層求めることが目的であった。どれだけ集まるかは，利用 者の環境保全意識の高さの一つの指標之捉えられる。チップ制の 結果は, 99 年度において, 富士吉田側が, 一人平均約 37.3 円, 富士宮側が約 10.3 円であった。特に吉田口の約 37.3 円という数 字は，上高地の駐車場に位置するトイレのチップ制導入時のもの とほぼ同額であったほか, 99 年度に山梨県が北岳大樺沢二俣に 
設置した公衆トイレに打ける状況（一人平均 36.6 円）上ほぼ同 額であり，チップ制への関心と理解が他の地域と比較して同様な 状況にあると言える。

（iii）美化推進会議の多面的活動

富士山地域美化推進会議は水解性ティッシュの作成・配布に限 らず，民間闷体の資金的協力を得て，多面的な事業を展開し，富 士山環境美化宣言, 富士山カントリーコードの普及啓発のための ポスター，ステッカー，下敷きの作成・配付等を実施している。 特にカントリーコードの普及は地元の子供たちへの環境教育の一 環という認識の下に富士山麓の 15 市町村の児童にカントリーコー ドを記載した下敷きを配付し，ゴミ問題は，広く環境保全の問題 と一体となって捉えられていった。

\section{（4）美化清掃活動団体の相互関係}

上述したとおり, 富士山地域の美化清掃活動は様々な付体が関 わってきている。各団体について, 組織の性質, 活動の継続性及 び役割等の観点から, 相互関係を次のように整理できる。(1)富士 山をきれいにする会は 1962 年の発足以来, 民間囘体の核として, 活動区域を山梨県側, 富士五湖地域を含めた富士山麓まで広げ,

一斉清掃の他，ボランティアによる美化清掃活動の中心的な役割 を果たし続けている。(2)77年の陸上自衛隊の活動自体は, 環境 庁の美化清掃活動の強化及び 79 年の富士山クリーン作戦に繋がっ たものの単発イベント的であった。(3)富士山クリーン作戦は, 以 後, 山梨・静岡それぞれの県下での一斉清掃に引き継がれた。 (4) 80 年に発足した富士山及び周辺美化推進協議会並びに富士山 をいつまでも美しくする会は, 以後, 環境庁の清掃補助金の受け 盀として, 県境の明確な富士山八合目以下の恒常的な清掃業務を 実施している。また，富士山をいつまで屯美しくする会は，静岡 県側の一斉清掃の中心となっている。(5)78 年に発足した富士山 自然環境保全対策会議は, 79 年の富士山クリーン作戦の実施決 定の他, 以後の各種環境保全対策の方向性を示した。95 年以降, その役割は新たに発足した富士山環境保全対策協議会が引き継ぎ, 様々な環境保全対策を検討・決定する場となっている。(6)特に美 化清掃活動については, 従来, 上記の富士山をきれいにする会, 富士山及び周辺美化推進協議会並びに富士山をいつまであ美しく する会等の施策が個々に実施されてきた状況であったため, 富士 山地域美化推進会議が美化清掃活動の取りまとめ役として発足, ·斉清掃等各種施策の一本化を推進している。

\section{4 . 富士山の美化清掃活動の社会的背景}

富士山の美化清掃活動の経緯を実態に即して見てきたが，この 社会的背景を考察する。

\section{（1）交通の発達と利用者の増大}

ゴミ問題が深刻化した背景には交通の発達と利用者の増大があっ た。戦後をみても, バス, タクシー等の交通機関の発達が利用に 影響をもたらしたが, 特に道路整備とモータリゼーションの進展 は大きな変化をもたらした。富土山においては，1950 年代から 徐々にバス運行が中腹まで延伸し，52 年には既に山梨県側で富 士山五合目までバスが到達, そして 64 年 4 月 1 日の富士山有料 道路（通称「富士スバルライン」）開通によって，既に利用者の 増大が始まっていたが, 富士スバルラインの開通以後も次々と交 通網が整備され ${ }^{17)}$, 現在の交通基盤が整えられた（表一2）。こ の時期, 利用者が更に增加する。山梨県側では, 69 年に中央自 動車道・調布〜河口湖間が全通して, 利用者（車両台数）が一気 に倍に急増した（図一2)。この急増以後も，7〜8月の夏期に 利用者が集中している。同様に静岡県側では, 70 年の表富士周 遊道路（通称「富士山スカイライン」）が全通し, 利用者が増大 する。富士山の利用は, 富士山スバルライン及び富士山スカイラ インの両有料道路と㥵まって, 中央自動車道・調布〜河口湖間の
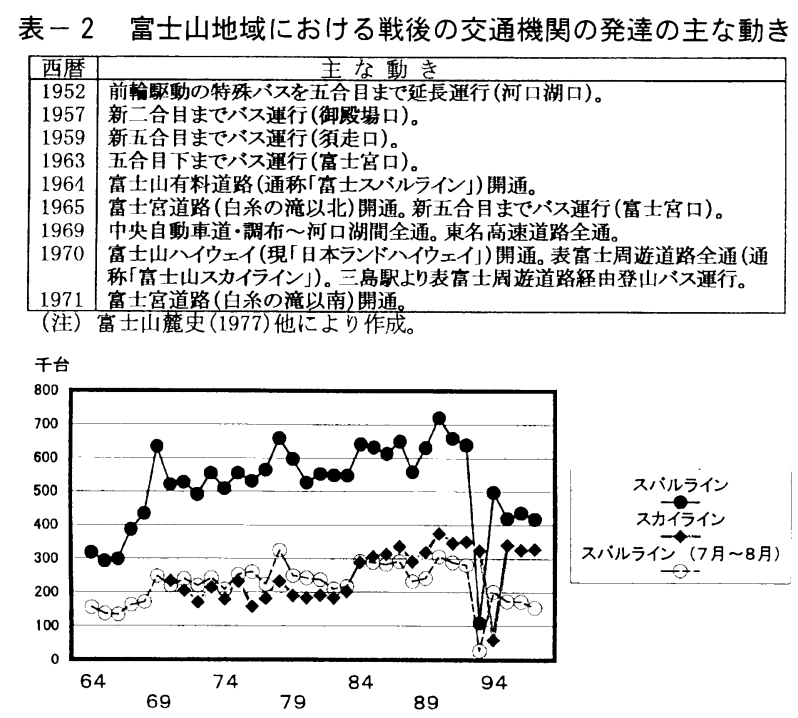

図－２富士スバルライン及び富士山スカイライン交通量 山梨県道路公社及び静岡県資料による。93年度はスバルライン災害による影響。 94 年度のスカイラインの交通量は $4 \sim 6$ 月までのもの。

全通により，69 年頃から利用者が急増するという大量利用時代 に入ったと捉えることができる。特に中央自動車道・調布〜河口 湖間の全通はエポック的な変化をもたらした。利用者の飛躍的増 大を招き，ゴミ問題が極めて深刻な状況になったといえる。

\section{(2) 景観問題から生態系問題への変化}

1979 年のクリーン作戦等, 美化清掃活動が様々に展開し, 本 格化していく背景には，ゴミ問題を景観問題として捉えることか ら, 生態系の問題として捉える見方が働いたといえる。富士スバ ルラインは開通当初から沿線のシラビソ等の原生林の各所に枯損 が目立ち自然破壊の代表例として様々に紹介された ${ }^{18}$ 。この富土 スバルライン建設による自然破壊問題は，景観保護から自然生態 系全体の保護に意識をシフトさせる方向に動くきっかけを与えた。 富士スバルライン開通当初の道路沿線の植生の破壊やゴミの散乱 は，高山・帚高山带における道路が自然生態系に及ぼす影響の大 きさを，地元住民のみならず広く国民に認識させ，美化清掃活動 への広範な参加を促したといえる。ゴミ問題は単なる見苦しさか ら自然破壊の問題へとシフトし, 美化清掃の意識もまた, 景観保 護から生態系保護へシフトしたといえる。

\section{（3）世界遺産登録運動の影響}

富士山を世界遺産に登録する動きは結果的に停滞したが，富士 山立体駐車場問題から世界遺産登録に向けての盛り上がりは様々 な形で影響をもたらした。世界遺産登録運動をきっかけに動き出 す 1995 年の富士山環境保全対策協議会の発足之緊急を要する環 境保全対策に関する中間報告, 96 年の富士山地域美化推進会議 の発足, 98 年の富士山環境保全対策要綱の策定等の一連の動き は, ゴミ問題の他，し尿処理問題をクローズアップするとともに， 96 年の富士山環境美化宣言, 98 年の富士山憲章の制定等につな がっていったと捉えることができる。世界遺産登録運動によって, 人々が富士山を環境保全の対象として新たなまなざしで捉えるよ うになったといえる。

\section{(4) 山梨県と静岡県の連携}

世界遺産登録運動に起因して美化清掃活動を含む広範な環境保 全活動が展開されるが，この展開を大きく支えたものに山梨・静 岡両県の連携があった。一連の動きの背景にある2 県の連携は, 従来なかったことであり, 活動を変化させていく大きな要因であった。

ところで，富士山頂上部の土地所有は，1974 年の最高裁判所 による上告裹却の判決により，一部を除き現富士山本宮浅間大社 の上地であることが確定したが, 山梨県と静岡県の県境は定まっ 
ていない。富士山を抱える山梨県と静岡県は, この県境問題も絡 み，政策が取りにくい状況にあり，これまで個別に独自の活動を 展開する場合が多かった。連携の胎動は, 79 年の富士山クリー ン作戦に見られたが, 前述の 96 年の富土山地域美化推進会議設 立後, 独自に実施されてきた一斎清掃は両県連携しながら実施さ れている。また前述の富士山環境美化宣言等を契機に両県の「富 士山はひとつ」との気運が盛り上がり, 富士山憲章に結びついた。 99 年には両県一体となった富土山憲章推進会議も発足し, 両県 の連携のもとに環境保全活動が推進されている。そして, 94 年 に富士スバルライン及び富土山スカイラインで個別に始まったマ イカー規制も，97年からは同一期間で実施される等, 両県の連 携は, 特に近年の様々な環境保全活動を支える基盤として機能し つつあるといえる。

\section{（５）環境保全意識の高まり}

1990 年代に入ると, 後述するとおり多様な環境保全活動が様々 な場で展開されていく。教育の場では, 富士宮市が市内にある中 学校の 91 年度の理科の授業を契機として, 92 年度から本格的に 富士山環境学習を開始した。また, 富士宮市教育委員会, 建設省 富士砂防工事事務所等 4 者は 96 年度加「富士山への手紙・絵 コンクール」を始めた。そして緑化事業の分野では, 富士市の富 士山麓ブナ林創造事業, 静岡県の富士山 100 年プロジェクト 3776 構想が始まり, 林野庁も, 96 年 9 月の台風 17 号による富士 南麓部国有林等被害の災害復旧のため, 静岡県, ボランティア団 体, 民間企業等とともに「富士山の森再生活動推進協議会」を結 成し, 植栽活動等を進めている。更に自然体験の促進及び富士山 地域における各種ボランティア活動の推進を図るため, 94 年に 河口湖町が富士山の自然を展示解説する河口湖フィールドセンター を整備, 99 年に静岡県が富士山の環境保全運動を全国的な広が りをもって展開していくため「ふじさんネットワーク」を立ち上 げ, 2000 年には山梨県が同様の目的で富士山ボランティアセン 夕ーを設置し, 環境庁も全国に先駆けて富士山麓の田貫湖畔に国 立の自然学校とも言うべき「田貫湖ふれあい自然塾」を開設した。 一方，民間を中心とした環境保全活動も幅広く展開されている。 1995 年に富士急行(株) は富士山の自然環境保全のために低公害 車を導入した。また, 富士山五合目以下の古道や旧登山道を復活 させようとする動きも起こり，97 年には多くの市民の協力によ り荒廃していた須山口登山道が復活した。さらに，97 年 9 月の 富士山自然の森づくり，98 年 3 月の富士山表富士宮口登山組合 員及び富士山本宮浅間大社を中心とした富士山エコ・トイレ勉強
会の設立, 同年 11 月には全国的展開を図る富士山クラブが設立 される等，地元を中心とした団体のみならず，全国展開を図る民 間組織が設立され，活発に環境保全活動を行っている。このよう な広範な取り組みの背景には環境保全意識の高まりがあったと捉 えることが出来る。

そして, 上記 3 の美化清掃活動の経緯から, 活動は開始, 本格 化, 環境保全活動との一体化へと発展したことがわかる。この発 展区分は上記 4 の交通・利用者, 景観・生態系問題，世界遺産登 録運動，山梨・静岡両県等の連携，環境保全意識の高まりという 社会的背景の变化と密接に関係している。美化清掃活動の発展と 社会的背景の変化から富士山の戦後の美化清掃活動の変遷の特徵 を次のとおり整理できる。

第 1 期（戦後〜1968 年頃）：富士山の 5 合目までバスが運行 し，1964 年の富士スバルライン開通により利用者が増大し，ゴ ミ問題が緊要化し, 深刻化していく時期である。東京オリンピッ ク前後の清掃活動の呼びかけに代表される「国土を美しくする運 動」を中核として，62 年に富士山をきれいにする会が誕生し， 美化清掃活動の基盤ができた時期である。東京オリンピックを背 景に国土美化の一環と捉えられた。

第 2 期（1969 年頃 1987 年頃）：69 年の中央自動車道・調布 〜河口湖間の全通により, 富士スバルライン及び富士山スカイラ インとも一体となって, 富士山の大量利用時代が到来する。ゴミ 問題も深刻化し，自衛隊や富土山をきれいにする会のみならず, 美化清掃活動が様々な形で本格化していく。79 年には富士山ク リーン作戦が大規模に展開され, 環境庁の清掃補助事業, 静岡県 側における一為清掃も始まり, 山梨・静岡両県において美化清掃 活動の基盤が強化され, 定着していく時期である。道路沿線のゴ ミの散乱自体も, 植生破壊とともに, 自然生態系に悪影響を及ぼ すものと捉えられ, 景観問題から生態系問題への変化のもと, 美 化清掃活動への広範な市民参加を促したといえる。

第 3 期（1988 年頃〜現在）：1988 年の土ダンゴ緑化の動き, 91 年の立体駐車場建設問題, 94 年の世界遺産登録運動, その後 のし尿処理問題の浮上等を通じて, 美化清掃活動は広範な環境保 全活動の一つとして捉えられるようになってくる。特に世界遗産 登録運動の影響は大きく，その後美化清掃活動を含む広範な環境 保全活動が展開されるが, この展開には, 山梨・静岡両県等の連 携, 連帯感があった。また, 環境保全意識の高まりという背景の 中で, 富士山の美化清掃活動と, 新しく生まれ出した環境保全活 動の大きな潮流が一体化していったと指摘できる。

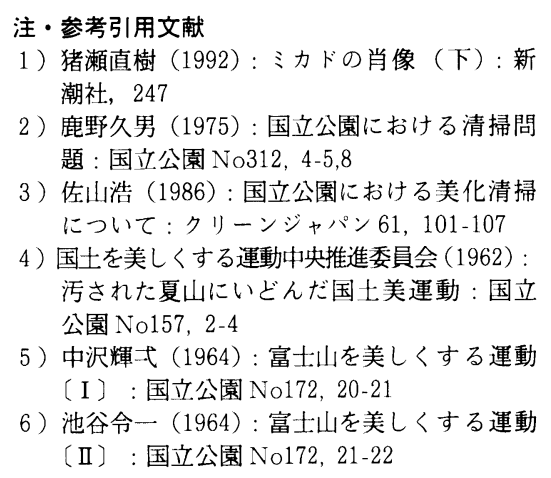

1) 猪瀬直樹 (1992)：ミカドの肖像 (下)：新 潮社, 247

2）鹿野久男 (1975)：国立公園における清掃問 題: 国立公園 No312, 4-5,8

3) 佐山浩 (1986)：国立公園における美化清掃 について:クリーンジャパン 61, 101-107

4) 国土を美しくする運動中央推進委員会 (1962) : 污された夏山にいどんだ国土美運動：国立 公園 No157, 2-4

5 ) 中沢輝士（1964）：富士山を美しくする運動 （I）：国立公園 No172，20-21

6) 池谷令一 (1964)：富士山を美しくする運動 （II)：国立公園 No172，21-22

7 ) 沖洸三 (1965)：夏の富士山頂：国立公園 No192, 9-11

8 ）小森順吉 (1970)：自然公園をき机いに 富 士山 : 国立公園 No249/250, 21-23

9) 日下部甲太郎・遠藤勝・石川甚三 (1979) 富士山クリーン作戦：かんきょう第 4 巻第 5 号, 63-79

10）財団法人自然公園美化管理財団（2000）：散 乱ゴミ対策実践活動資料, 59-63

11）無記名：自然公園をきれいに一集団施設地 区美化清掃対策 : 国立公園 No245, 30

12）山梨日日新聞, 平成 12 年 7 月 3 日朝刊「や まなし 20 世紀の群像 60 富士山美化運動」

13）静岡新聞，昭和 52 年 7 月 17 日朝刊
14）讀賣新聞，平成 12 年 9 月 5 日朝刊（ライン ホルト・メスナー来日関連記事)。また，国 の清掃事業の 1969 年と 99 年の実績を比較 すると，1人/日当たりゴミ収集量は，50 $\mathrm{kg}$ (小森 (1970)) 加約 $6 \mathrm{~kg}$ 之ほぼ 8 分の 1 に隇少している。

15）每日新聞（山梨版），平成 3 年 10 月 3 日朝 刊

16）週刊文春, 平成 10 年 4 月 9 日発行：富士山 の “白い川”, 97

17）富士急行株式会社（1977）：富士山麓史

18）宮脇昭 (1970)：生物社会のバランス「NH Kブックス 109 植物と人間」: 日本放送出 版協会, $117-119$

Summary : About the beautification and cleaning activities of Mt. Fuji after World War II, this paper explains the characteristics of its transition and positions the national history through from the social background. The effects are as follows. 1.The activities started one of the national land beautification and cleaning activities before the Tokyo Olympics. 2.Its garbage problem had been serious with development of transportation and visitors increase, changing to a ecological problem from a landscape problem, and even more people participated in the activities. 3.And after the opportunities of World Heritage designation campaign etc., various environmental conservation activities have been uniting with the cooperation of Yamanashi and Shizuoka prefectures and other organizations, and the increase of environmental conservation consciousness. 